\title{
Saminist's Indigenous Knowledge in Water Conservation in North Karts Kendeng Sukolilo
}

\author{
Endrat Mojo ${ }^{1 凶}$, Sudharto P. Hadi, Hartuti Purnaweni \\ ${ }^{1}$ Diponegoro University
}

Permalink/DOI: http://dx.doi.org/10.15294/komunitas.v7i2.4048

Received : August 2015; Accepted: September 2015; Published: September 2015

\begin{abstract}
Saminist is indigenous peoples and a local communities at North karts Kendeng. Saminist expected that North Karts Kendeng maintained and conserved continuity to be able to contribute to the life around this region especially abundant water. Water is one of the main needs of living beings on Earth, besides that water is a primary requirement of farmers in farming communities. Saminist as traditional community who only permitted to be farmers still practice the environmental wisdom from their heritage which aims to preserve the natural environment so that they could alive depend on nature around, especially Saminist just sack their business of farming crops that are not market oriented as much farming is done farmers in general. They tried to maintain a relationship of harmony between communities around the North Karts Kendeng to conserve North Karts Kendeng region from mining destruction, the negative impacts from mining in this region was disappears of water and others impacts such as natural disaster, flood, rough, and danger of tornado. North Karts Kendeng Sukolilo have 79 springs and 24 caves spread across 3 sub-district namely Sukolilo, Kayen and Tambakromo. Abundant natural resources certainly is a gift that needs to be maintained and conserved. To maintain and conserve this region with planting the three, not mining the rocks, maintain local wisdom, and refusal cement industry in North Karts Kendeng Sukolilo.
\end{abstract}

Keywords: Saminist; water; indigenous knowledge; spring

\section{INTRODUCTION}

Samin tribe was indigenous peoples, they were part of Javanese but they had different ethic, norm and tradition with Javanese generally. Saminist mean a group of people who are trying to run daily life in accordance with the teachings of Samin. Samin community which is mostly found in rural areas in Central Java and East Java. Samin Surosentiko is the founder of the doctrine saminisme (Darmastuti and Purworini 2014; Darmastuti and Purworini 2014). He was born in 1859 with the name Raden Kohar Ploso Kedhiren village, Randublatung Blora regency, Central Java. His father named Raden Surowijaya or Samin Sepuh. He changed his name to Samin Surosentiko because Samin is a name that had meaning underprivileged. The moral values are still maintained at Samin groups include: honesty, simplicity, coope- ration and hard work. Samin community still has a very strong tradition in everyday life. These communities still adhere to the teachings of their ancestors, especially the values that govern relations Samin community with the natural surroundings (Maridi, Agustina and Saputra 2014; Rohman 2010; Widodo 2012). This study gives an addition to the existing literatures on the relevance of indigenous knowledge in the modern world (Ahmad and Prashar 2010; Kurz, T Donaghue and Walker 2005; Kurz, Roberts and Rosen 2009; Ward and Pulido-Velazquez 2008; Williams, Blanco and Lal 2010). This study is important in the way it gives attention to the practice of water conservation strategy among a well-known traditional community in Java.

Samin community depend on the goodness of nature for their life. As tradi-

\footnotetext{
Corresponding author:

Address: SMK BTB Juwana. J1. Maling Mati 109 Juwana,

Pati, Central Java, Indonesia

Email : mojoendrat@yahoo.com

Telp : 081325258935
}

(C) 2015 Semarang State University. All rights reserved p-ISSN 2086 - 5465 | e-ISSN 2460-7320

UNNDS JOURNALS




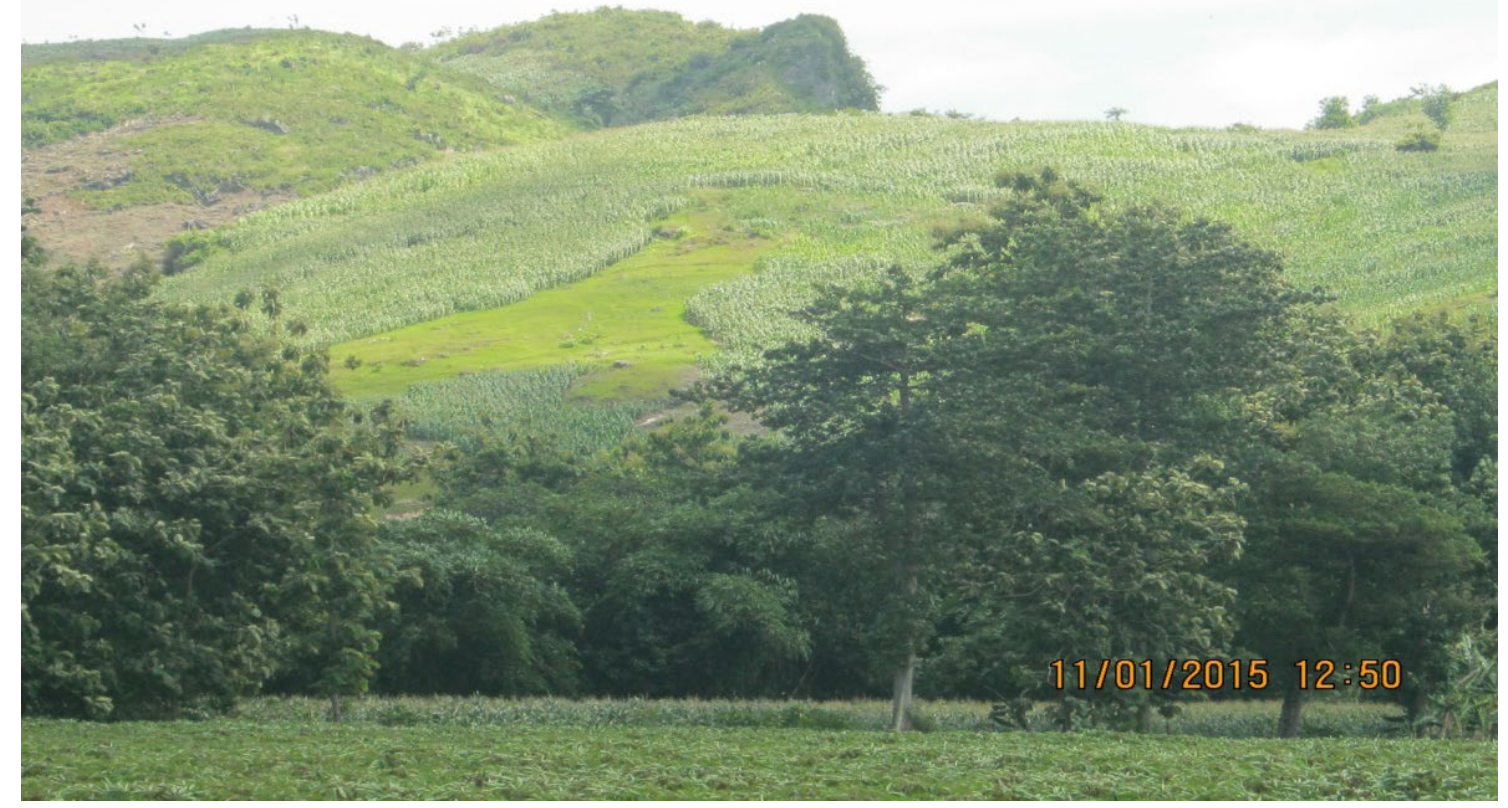

Pictute 1 : North Karts Kendeng Sukolilo

tional farmers, They had a very high dependence on natural resources and environment. North Karts Kendeng mountains as karts region that had some uniqueness compared to the mountains in general. The mountains seem barren and dry, but It was as a giant water reservoir, water will be pouring various areas around it. Water is one of the primary needs of living thing. Farmers around North Karts Kendeng required irrigation water from several springs in the surrounding mountains. To maintain their sustainability and conserved the water in many springs in North Karts Kendeng They corcerned great lengths to preserve the nature around North Kendeng Mountains (Cahyolestari 2010).

North Karst Kendeng stretch covering five regency in Central Java Province, including: Kudus, Pati, Grobogan, Rembang, and Blora. Based on Indonesian Government Regulation No. 26 , issued 2008 on the National Spatial Plan, the region that has a karts landscape is a protected area geology. Karst is a term in German that is derived from the Slovenian meaning rocky barren land (Adji et al., 2006). The term actually describes the conditions that are often encountered in many areas of rocky carbonate or rock that is easily soluble (Haryono 2001). More specific definition expressed by Ford and Williams (1992) that define a field with characteristic karts hydrology and land forms caused by a combination of rock-soluble and has a welldeveloped secondary porosity well. While Ford and Wiliams defined as a karts terrain with typical hydrologic conditions as a result of rock-soluble and has a well developed secondary porosity. Karts is characterized by: (i) the presence of a closed basin or dry valleys in various sizes and shapes, (ii) the absence of rare or drainage / river surface, and (iii) the presence of a cave underground drainage system (cahyadi, 2010).

Karts is a general term used for a region in which the constituent rock is limestone that has undergone a process of dissolution. Limestone is carbonate (containing $\mathrm{CaCo}_{3}$ ) so easily dissolved by rainwater containing acidic. If limestone karts region is said to have undergone a karts process (Arsyad, 2014). Karts process was a series of processes ranging from lifting of limestone to the earth's surface as a result of an endogenous process and a process of dissolution in space and geological time until eventually produced landforms karts (Haryono 2004). Process by rain water on the surface of the produce landscapes ecsokarts distinctive, namely Karren or conical hill, the karts to- 
wer, the valley / topography negative among a set of hills cone (doline), lake karts, river periodic culminate in a vertical cave (sinkhole), water inlet hole (ponour), the surface of the river disappeared into the mouth of the cave (shallow holes), and irregular valleys that dead end (blind Valey). Furthermore, the dissolution process evolved to produce subsurface formations below the surface (endokarts). The process produces a complex network of passageways to the type and size varies form cave system or the underground river system (UPN, ASC Disaster Management Studies Center, ASC, p. 2008)

\section{RESEARCH METHODS}

The research was conducted in the Baturejo village, Hamlet Bombong and Bacem, Sukolilo District Pati Regency. In two hamlet is the indwelling of Samin community, the population surrounding better known as Sedulur Sikep. The indigenous peoples still practice the teachings Saminisme as a legacy of their predecessors. The data in this study is not just limited to people Saminist or Sedulur Sikep but they are also obtained from several stakeholders such as Governments institutions, communities surrounding, civil society organizations and Karts Kendeng observer. Baturejo Village consists of four hamlets namely Bombong, Ronggo, Mulyoharjo and Bacem. The village area has a slope of $8 \%$ and is at $150-120$ meters above sea level. Wide Baturejo village is 946.50 hectare. Most of this village, $+90 \%$, or 845 hectares, is dominated by agricultural land. Baturejo village had a population of 6077 inhabitants. Consisting of 3073 men and 3004 women. Baturejo population majority of the villagers are farmers.

This study is a qualitative research that does not depart from a theory but of social phenomenon through a particular process will be a theory. Qualitative research is referred to as grounded research because it departed from the bottom (ground) or from social reality instead of behind desks This research uses descriptive method, which means method used to examine the status of a group of people, an object, a condition, a system of thought or a class events (Nasir
1988, p.63). While Suharsini Arikunto (2003, p.310) asserts that descriptive study was not intended to test a particular hypothesis, but simply to portray what it is about a variable, symptoms or conditions. The data in this study consisted of primary and secondary data, primary data is data obtained directly from the research area while secondary data means data obtained from other sources such as books, media, government and mass organizations. Data collection techniques is the main participant observation, interviews, and documentation and the combination of three or triangulation.

\section{RESULT AND DISCUSSION}

Sukolilo Karts region serves as a water catchment area and storage for many springs that flow in settlements in the area of North Karts Kendeng Sukolilo, Kayen and Ta Sumber lawang spring mbakromo. Water resources in the karts region is a valuable asset for the community around the Karts region. Almost all people who lived in the region of North Karts Kendeng such as Sukolilo, Kayen, Tambakromo Districts, almost Pati Regency region utilize water resources derived from Karts Kendeng Sukolilo, because 90\% of water supply comes from North Karts Kendeng Region. Almost every village in Sukolilo district was founded spring, Sukolilo Village (19 springs), Gadudero Village (3 springs), Tompe Gunung Village (21 springs), Kayen Village (4 springs), Kudumulyo Village (1 springs), Mlawat Village (1 springs), Baleadi Village (3 springs), Sumbersuko Village (24 springs) in the District Sukolilo have sources of springs which have varied flow rate of 1 liter / sec up to 178.90 liters / sec. The most source of water in Sukolilo districts namely Sumber Lawang located in the Tengahan Hamlet, Sukolilo Village, District Sukolilo. This spring flowed water in the dry season 178.90 liters / sec. This spring is able to meet the water needs of more than 2000 households in the district Sukolilo, because this source is the main source of the flow surface is joined by several springs in the surrounding areas so that it becomes a river surface of which has the largest flow and used for fulfilling 
the daily needs such as; washing, toilets, livestock, basic daily needs and as an irrigation channel to more than 4000 hectares of paddy fields in the village of Sukolilo. It also spring of Lawang also been used as micro hydro power plants to meet electricity needs in Tengahan.

From several springs in the District Sukolilo the smallest flow rate of 0.06 liters / sec, is Ngowak spring located Tompe Gunung village, Distric Sukolilo t. This condition does not include the discharge pipe flow that has been utilized in this water spring, this spring is able to meet the water needs of 40 households in the Tompe Gunung Village. Every source of water in Kars Region Sukolilo able to meet the average needs of the community water more than 200 families in each hamlet or village Utilization of water per day for one person is about $15^{-20}$ liters, can be calculated if one household using water for daily needs day can reach 100 liters. This may indicate that the available water resources in the area of Kars Sukolilo water demand exceeds the capacity of the community, and the others also used mostly for agricultural lands and farms.

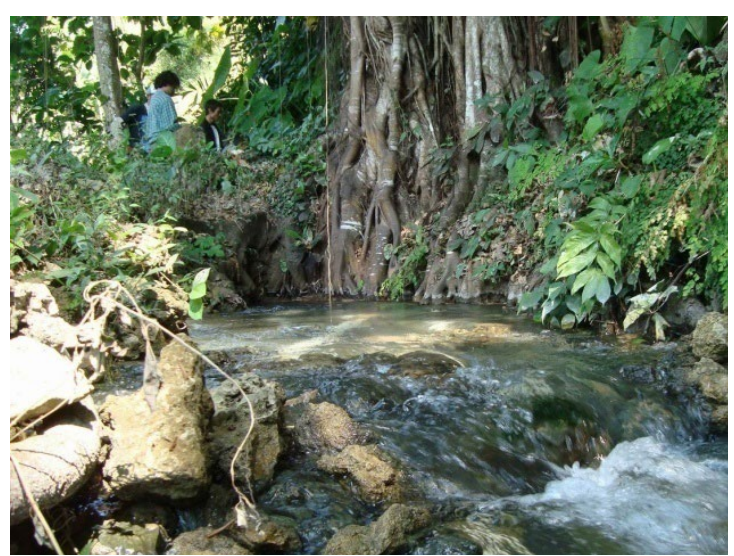

Picture 1. Sumber lawang spring in North Karts Kendeng Sukolilo

Sumber Lawang is as greatest spring in Karts Kendeng Sukolilo, the more than 4000 housholds araound this location need the water from this spring.

Table 1. Spring Water Potential in North Karts Kendeng Sukolilo, Pati, Central Java

\begin{tabular}{|c|c|c|c|c|c|c|c|}
\hline \multirow[b]{2}{*}{$\mathrm{NO}$} & \multirow[b]{2}{*}{ Village } & \multirow[b]{2}{*}{ Name of Spring } & \multicolumn{2}{|c|}{ Coordinate } & \multirow{2}{*}{$\begin{array}{c}\text { Elevation } \\
\text { (Above } \\
\text { sea level) }\end{array}$} & \multirow[b]{2}{*}{$\begin{array}{c}\text { DEBIT } \\
\text { (Liter/s) }\end{array}$} & \multirow{2}{*}{$\begin{array}{c}\text { House- } \\
\text { hold } \\
\text { Users }\end{array}$} \\
\hline & & & $\mathrm{X}$ & Y & & & \\
\hline 1 & Tompe Gunung & Pring & 495380 & 9232604 & 265 & & \\
\hline 2 & Tompe Gunung & Sono & 495217 & 9232632 & 232 & & \\
\hline 3 & Tompe Gunung & Gosangen & 495138 & 9232685 & 234 & $37 \cdot 50$ & \\
\hline 4 & Tompe Gunung & Ngreceh & 495278 & 9232249 & 259 & & \\
\hline 5 & Tompe Gunung & Nggowak & 495254 & 9232110 & 277 & 0.06 & 400 \\
\hline 6 & Tompe Gunung & Sobrah & 495145 & 9231814 & 303 & & \\
\hline 7 & Tompe Gunung & Kembang & 495159 & 9231614 & 296 & 0.40 & \\
\hline 8 & Tompe Gunung & Pring II & 495190 & 9231555 & 292 & 6.70 & 400 \\
\hline 9 & Tompe Gunung & Tileng & 495165 & 9231385 & 292 & & 200 \\
\hline 10 & Tompe Gunung & Gentungan & 495377 & 9231337 & 305 & 0.46 & 250 \\
\hline 11 & Tompe Gunung & Jeruk Bulung & 494675 & 9231892 & 280 & & 500 \\
\hline 12 & Tompe Gunung & Dhanyangan & 494730 & 9231499 & 296 & & 150 \\
\hline 13 & Tompe Gunung & Anonim & 494809 & 9231534 & 295 & & \\
\hline 14 & Tompe Gunung & Dringo & 496293 & 9232261 & 271 & & \\
\hline 15 & Tompe Gunung & Telogo Mbah Dirjo & 496611 & 9232815 & 155 & & \\
\hline 16 & Tompe Gunung & Deleg & 496262 & 9232058 & 231 & 11.88 & \\
\hline 17 & Tompe Gunung & Bulusan & 496216 & 9232125 & 227 & & \\
\hline 18 & Tompe Gunung & Pucung & 496467 & 9230914 & 270 & $45 \cdot 93$ & 28 \\
\hline 19 & Tompe Gunung & Kaligede & 496998 & 9231083 & 226 & $19 \cdot 53$ & \\
\hline 20 & Tompe Gunung & Kompan & 497156 & 9231156 & 215 & & \\
\hline 21 & Tompe Gunung & Blekuthuk & 496765 & 9231306 & 231 & & 400 \\
\hline 22 & Sumber Soko & Sendang Penatas & 493396 & 9231292 & 206 & 0.38 & 50 \\
\hline
\end{tabular}




\begin{tabular}{|c|c|c|c|c|c|c|c|}
\hline 23 & Sumber Soko & Pandanan & 493397 & 9230984 & 287 & 8.88 & \\
\hline 24 & Sumber Soko & Klampok & 493358 & 9230991 & 290 & & 4 \\
\hline 25 & Sumber Soko & Nglemprak & 493480 & 9230868 & 300 & 0.20 & 50 \\
\hline 26 & Sumber Soko & Pancuran & 492671 & 9231037 & 260 & 22.19 & 150 \\
\hline 27 & Sumber Soko & Keceh & 492155 & 9231454 & 235 & 83.50 & 70 \\
\hline 28 & Sumber Soko & Keceh II & 492117 & 9231448 & 248 & & 70 \\
\hline 29 & Sumber Soko & Lebak & 491652 & 9231055 & 228 & 14.64 & \\
\hline 30 & Sumber Soko & Cilik & 491936 & 9230918 & 244 & 0.94 & \\
\hline 31 & Sumber Soko & Bendo & 492005 & 9230977 & 248 & 4.29 & \\
\hline 32 & Sumber Soko & Gayam & 491877 & 9230562 & 272 & 10.50 & \\
\hline 33 & Sumber Soko & Sumber Soko 1 & 492711 & 9229284 & 318 & 19.44 & \\
\hline 34 & Sumber Soko & Sumber Soko 2 & 493333 & 9229616 & 325 & & \\
\hline 35 & Sumber Soko & Sumur 1 & 493854 & 9229672 & 336 & & \\
\hline 36 & Sumber Soko & Sumur 2 & 493834 & 9229698 & 338 & & \\
\hline 37 & Sumber Soko & Sumur 3 & 493816 & 9229686 & 335 & & \\
\hline 38 & Sumber Soko & Sumur 4 & 493784 & 9229714 & 339 & & \\
\hline 39 & Sumber Suko & Sumur 5 & 493808 & 9229635 & 338 & & \\
\hline 40 & Sumber Suko & Sumur 6 & 493897 & 9229640 & 335 & & \\
\hline 41 & Sumber Suko & Sumur 7 & 493962 & 9229688 & 334 & & \\
\hline 42 & Sumber Suko & Sumur 8 & 494033 & 9229682 & 332 & & \\
\hline 43 & Sumber Suko & Sumur 9 & 494050 & 9229651 & 340 & & \\
\hline 44 & Sumber Suko & Sumur 10 & 494081 & 9229673 & 344 & & \\
\hline 45 & Sumber Suko & Sumur 11 & 494106 & 9229659 & 346 & & \\
\hline 46 & Sumber Suko & Sumur 12 & 494102 & 9229698 & 341 & & \\
\hline 47 & Sukolilo & Sapi & 490548 & 9233401 & 54 & 8.90 & 500 \\
\hline 48 & Sukolilo & Kalangan & 491826 & 9234416 & 23 & 16.90 & \\
\hline 49 & Sukolilo & Tambang & 490163 & 9233268 & 47 & 24.80 & \\
\hline 50 & Sukolilo & Duayah & 490545 & 9233128 & 70 & 22.50 & 300 \\
\hline 51 & Sukolilo & Kalireco & 490464 & 9232962 & 71 & 13.50 & 75 \\
\hline 52 & Sukolilo & Sumber & 490472 & 9232438 & 90 & 3.40 & 150 \\
\hline 53 & Sukolilo & Sumber Bendo & 490598 & 9232173 & 126 & 23.80 & 350 \\
\hline 54 & Sukolilo & Banyu Biru & 491321 & 9232196 & 153 & & \\
\hline 55 & Sukolilo & Sumber Dudukan & 491800 & 9231817 & 189 & & 50 \\
\hline 56 & Sukolilo & $\begin{array}{l}\text { Sumber Kedunga- } \\
\text { ron }\end{array}$ & 492003 & 02222224 & 161 & & 500 \\
\hline 57 & Sukolilo & Sumber Gemblung & 490918 & 9231784 & 197 & & 500 \\
\hline 58 & Sukolilo & Anonim & 491114 & 9232690 & 122 & & 500 \\
\hline 59 & Sukolilo & Sumber Lawang & 491332 & 9231950 & 159 & 178.90 & \\
\hline 60 & Sukolilo & Sumber Getuk & 491587 & 9231572 & 175 & 6.60 & \\
\hline 61 & Sukolilo & Sumber Geceh & 492140 & 9231457 & 235 & 49.26 & 50 \\
\hline 62 & Sukolilo & Sumber Pucung & 491314 & 9233116 & 81 & 32.30 & 100 \\
\hline 63 & Sukolilo & Gayam & 491333 & 9233014 & 96 & & \\
\hline 64 & Gadudero & Kepoh & 492084 & 9234465 & 16 & 26.60 & \\
\hline 65 & Gadudero & Grubug & 492237 & 9234460 & 22 & 63.60 & \\
\hline 66 & Gadudero & Sumber Krawon & 492960 & 9234589 & 25 & 16.50 & \\
\hline 67 & Kedu Mulyo & Asem Bosok & 495823 & 9234518 & 104 & 48.20 & \\
\hline 68 & Kayen & Sumber Ndodo & 497231 & 9234117 & 46 & 8.40 & \\
\hline 69 & Kayen & Sumber Glatik & 497530 & 9234389 & 37 & & \\
\hline 70 & Kayen & Sumur Tuang & 496538 & 9234018 & 49 & & \\
\hline 71 & Kayen & Sumur Tuang & 496538 & 9234018 & 49 & & \\
\hline 72 & Kedung Winong & Lanang & 489175 & 9233096 & 44 & 2.52 & \\
\hline
\end{tabular}




\begin{tabular}{lllllll}
73 & Kedung Winong & Wedok & 488929 & 9233033 & 44 & \\
74 & Kedung Winong & Dukuh Pacul & 488696 & 9232268 & 104 & 36.89 \\
75 & Baleadi & Cendi & 486614 & 9232709 & 31 & 22.40 \\
76 & Baleadi & Beji & 486635 & 9232820 & 35 & 71.86 \\
77 & Mlawat & Giwang & 486417 & 9232574 & 35 & 44.11 \\
78 & Sukolilo & Belik Ungu & 492826 & 9232316 & 255 & \\
79 & Sukolilo & Belik & 492473 & 9232093 & 252 & \\
\hline
\end{tabular}

( Data Source : Acintyacunyata Speleological Club (ASC) Yogyakarta : 2008)

The Saminist community only permitted by their tradition earned living as farmer that planted the crops for their daily life. They didn't plant the crops base on market oriented. They only wanted to be self sufficient community. Saminist community fulfill their daily need by themselves, they didn't depend on other community. They didn't get education from formal school, so they only got education reading and writing but they had many tradition, ethic, and norm in this traditional community, one of them to live harmony with nature. Conserving North Karts Kendeng was their ethic to sustain their community living. Water is a basic need for sustainable human being, beside that water is needed for agriculture activities. Saminist would like to conserve nature around North Karst Kendeng, some Saminist ways to conserve water spring in North Karts Kendeng such as :

1. Saminist promoted to society in North Karts Kendeng around to plant three voluntary such as Mahagony, acacia, cashew, teak and others kind of indigenous three in Java Island to keep the spring in order to flow the water every time and preserving this region from mining destruction.

2. Saminist take the leads society around North Karts Kendeng not to mine limestone and others rocks in this region because it can disturb in hydrology system in river underground. They can take the rocks in this region only for their need not for sell. They believed that destructing the rock and natural resources such as plant, animal, rocks cause the natural balance.

3. Saminist take the leads to refuse the building the Corporation of Gresik Cement at 2008 and the building of Indocement at 2010 in region of North
Karts Kendeng. Pthe planning of the building of cements industries in this region have got permission from local government and Indonesian government but they have believed that this project will destruct nature Karts Kendeng Sukolilo. Finally the water sources will be eliminated or disappears like the condition in Gresik, Maros, Tuban and others region that was built the cement industries. This condition will make the society around difficult fulfill water need in daily life.

4. Saminist conserved the spring with planting threes to sustain water sources in spring, and they had local wisdom not to cut down the three at spring areas.

\section{CONCLUSION}

The availability of water in North Karts Kendeng depends on the preservation of this region. Damage or destruction of this region as the impacts of mining rocks, cutting down trees in the forest would have negative impacts in a lack of water resources. Water is a primary human need. Population around this region especially Saminist use the water for their daily needs and for irrigation on their farms. Governments and investors planned to build this region as an area of mining rocks such as limestone as cement raw materials is contrary to the interests of local communities. Saminist as a traditional communities who have lived in the area from generation to generation rejected the plan of government and Semen Gresik Co.Ltd and Indo cement Co.Ltd. Saminist took a lead other local communities to refuse this plan. Finally Saminist community and other local population got success to refuse this project. Saminist has conserve the region by means of planted three forest 
area and around the springs, voluntary forbids people to take the rocks to be commercialized, rejecting the exploitation of North Karts Kendeng industries as areas especially cement industries, keeping saminist's local wisdom to conserve North Karts Kendeng.

\section{REFERENCES}

Adji, T.N., 2010. The Spatial-Temporal Variations hydro chemical and flow properties for Karts Dynamic System Characterization Underground River Karts Gunungkidul, Yogyakarta. Dissertation. Faculty of Geography, University of Gadjah Mada.

Arsyad, M., 2014. Analysis of the Underground River Water Availability and Its Sustainable Uses Area at Karts Maros in South Sulawesi, Journal of Human and Environment, 21(1)

Arikunto, S., 2003. Research Management. PT. Rineka Cipta, Jakarta.

ASC.UPN, JMPPK. 2008. Reports Kars Hydrology and Water Resources Utilization Sukolilo area, Disaster Management Studies Centre UPN "Veteran" Yogyakarta. Acintyacunyata Speleological Club (ASC) Yogyakarta, the Community Care Network Kendeng Mountains

Cahyadi, A., 2010. Management of the Karst and its Role in Carbon Cycle in Indonesia. Papers in the National Seminar on Climate Change in Indonesia. Graduate School of UGM, October 13, 2010.

Cahyolestari, D.P., 2010. Proposing an Appropriate Land Use Based on Hydrological Analysis with
State Regulations: A Case Study of Samin Watershed, Central Java, Indonesia. University of Twente Faculty of Geo-Information and Earth Observation (ITC).

Darmastuti, R. and Purworini, D., 2014. Intercultural Communication in The Samin Community's Movement as the Oldest Movement in Southeast Asia: The Case in The Construction of a Cement Factory in Sukolilo, Pati, Central Java. Ford, D. and Williams, P., 1992. Karst geomorphology and Hydrology. Chapman and Hall, London.

Haryono, E., 2001. Value Hydrological Hill Karst. Papers at the National Seminar, Eco-Hydraulic. 28-29 March 2001. Civil Engineering Department, Gadjah Mada University.

Haryono, E. 2004. Life Friends with Karst. Forum Karst Goenoeng Sewoe, Yogyakarta.

Miles, M.B. and A. Michael, H., 2007. Qualitative Data Analysis: Resource Book On-method New Method. UI Press, Jakarta.

Nasir. 1992. Research Methodology. Ghalia Indonesia, Jakarta.

Maridi, M., Agustina, P. and Saputra, A., 2014. Vegetation analysis of Samin watershed, Central Java as water and soil conservation efforts. Biodiversitas Journal of Biological Diversity, 15(2).

Rohman, A., 2010. Rumours and Realities of Marriage Practices in Contemporary Samin Society. $\mathrm{Hu}$ maniora, 22(2), pp.113-124.

Widodo, Y., 2012. Food from the forest of Java: tropical agro-forestry experiences in feeding dwellers and keeping the environment greener. Sustainability Today. Wessex Institute of Technology (WIT) Press, Southampton, Boston. Printed in UK, pp.281-393. 